BNL 879 (I-354)

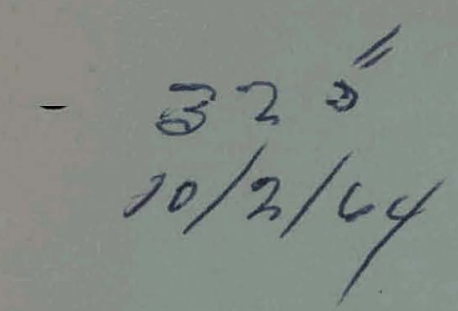

\title{
MASTER
}

\section{SOME ANCIENT GLASS SPECIMENS WITH COMPOSITIONS OF PARTICULAR ARCHAEOLOGICAL SIGNIFICANCE

\author{
EDWARD V. SAYRE
}

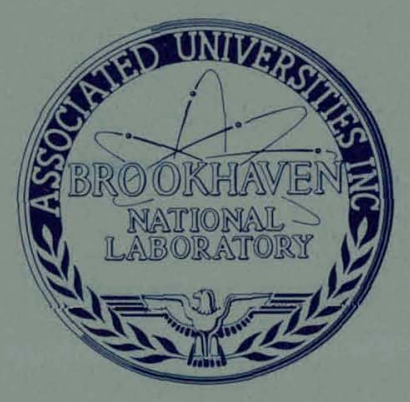

July 1964

BROOKHAVEN NATIONAL LABORATORY ASSOCIATED UNIVERSITIES, INC.

under contract with the UNITED STATES ATOMIC ENERGY COMMISSION 


\section{DISCLAIMER}

This report was prepared as an account of work sponsored by an agency of the United States Government. Neither the United States Government nor any agency Thereof, nor any of their employees, makes any warranty, express or implied, or assumes any legal liability or responsibility for the accuracy, completeness, or usefulness of any information, apparatus, product, or process disclosed, or represents that its use would not infringe privately owned rights. Reference herein to any specific commercial product, process, or service by trade name, trademark, manufacturer, or otherwise does not necessarily constitute or imply its endorsement, recommendation, or favoring by the United States Government or any agency thereof. The views and opinions of authors expressed herein do not necessarily state or reflect those of the United States Government or any agency thereof. 


\section{DISCLAIMER}

Portions of this document may be illegible in electronic image products. Images are produced from the best available original document. 


\title{
SOME ANCIENT GLASS SPECIMENS WITH COMPOSITIONS OF PARTICULAR ARCHAEOLOGICAL SIGNIFICANCE
}

\author{
EDWARD V. SAYre
}

July 1964

BROOKHAVEN NATIONAL LABORATORY UPTON; NEW YORK 


\section{LEG A L NOTICE}

This report was prepared as an account of Government sponsored work. Neither the United States, nor the Commission, nor any person acting on behalf of the Commission: - A. Makes any warranty or representation, expressed or implied, with respect to the accuracy, completeness, or usefulness of the information contained in this report, or that the use of any information, apparatus, method, or process disclosed in this report may not infringe privately owned rights; or

D. Assumes any lialsilities will respere: to the use of or for damages resulting from the use of any Information, apparatus, method, or process disclosed in this report.

As used in the above, "person acting on behalf of the Commission" includes any employee or contractor of the Commission, or employee of such contractor, to the extent that such employee or contractor of the Commission, or employee of such contractor prepares, disseminates, or provides access to, any information pursuant to his employment or contract with the Commission, or his employment with such contractor

\section{PRINTED IN USA \\ PRICE 75 CENTS$$
2000
$$

Available from the

Office of Technical Services

Department of Commerce

Washington 25, D.C. 


\title{
SOME ANCIENT GLASS SPECIMENS WITH COMPOSITIONS OF
}

\author{
PARTI OULAR ARCHAEOLOGI CAL SIGNIFICANCE
}

Much can be inferred from a knowledge of the composition of ancient artifacts, particularly of those fabricated from materials such as glass and a11oys which were compounded by man. Certain aspects of the technology by which they were produced can be revealed by chemical analysis. For example, the essential furnace conditions, e.g., fusion temperatures and oxidative or reductive atmosphere required to produce the final chemical state of a material, can be estimated from the composition. The nature of the raw materials of manufacture often can be deduced. Occasionally a raw material from a specific geographic site would have been characterized by a distinctive pattern of accompanying impurities and this pattern would have been introduced recognizably into the final artifact. The identification of special additives employed to introduce or remove color, opacity, etc., is usually relative1y obvious because they introduce unusually high concentrations of elements which are commonly present only as trace impurities. All of these aspects of materials and methods of ancient technology are intrinsical1y interesting. In addition, however, because there were sometimes characteristic regional and chronological variations in these materials and methods of fabrication, just as there were significant variations in styles of construction, the resulting compositional variations can in some instances indicate conclusions of archaeological significance. As is the case with stylistic inference, the more extensive the number and variety of objects examined the more significant an individual observation becomes as it is compared to the accumulated background of experience. The program of chemical analys is of more than four hundred careful1y selected specimens of ancient glass undertaken at Brookhaven Nationa1 Laboratory in collaboration with Mr. Ray Winfield Smith, when considered with the several hundred other analyses of ancient glass existing in the 1iterature, begins to provide a background of standard data for such comparison. The over-a11 Brookhaven program has striven to survey reasonably uniformly the glass produced in Europe, Western Asia and Northern Africa from the middle of the Second Millennium B.C., when glass vessels first became 
prevalent, until the beginning centuries of the Second Millennium A.D., when the medieval potassium-rich glasses were introduced. It is the purpose of this report to select from the Brookhaven data the analyses of a few specific specimens which indicate conclusions of particular archaeological interest.

It has been our experience that the basic compositions of ancient , glasses tend to conform to only a few types..$^{1,2}$ In our initial studies we, to a great extent, restricted our analyses to transparent glasses which appeared at most to be accidentally discolored in order to allow us to determine these basic compositions divorced from complications due to the addition of colorants or opacifiers. One finds, however, that with but a few exceptions colorants and opacifiers were added in concentrations of only a few percent or less and that the basic composition of the modified glass is essentially that of the basic type to which it relates. Therefore,statistically significant increases in concentrations in colored glasses over those in related uncolored glasses norma11y can be assumed to have been introduced by components of the colorant. Once the types of basic glass have been determined one has two independent criteria for the evaluation of a glass in which an additive has been incorporated, i.e., 1) recognition of the basic composition and 2) evaluation of the composition of the additive from the pattern of significantly increased concentrations.

Similarities in Some First Century Multicolored Luxuryware Fragments̀

A particularly straightforward and interesting example of the separate significance that can be assigned to hasic glass and additive compooitions is provided in the analyses of several separate regions of different color in three especially elaborate multicolored vesse1s of probable 1st century A.D. manufacture. These three multicolored vesse1s had been fabricated with very similar, complex structures. The irregular mosaic patterns of their walls al1 contain regions of transparent, colorless glass with imbedded material and regions which superficially appear to be opaque green and opaque dark blue: Thin opaque white layers separate sume of these color regions, and two of the specimens have thin insertions of a reddish violet glass. Closer examination revealed that in all three objects the regions that appear to be opaque green we re actually formed of a limpid light blue glass in which a medial opaque yellow layer had been embedded. Similarly the glass of the dark blue regions was not.itself opaque but contained in each.instance a thin 
medial opaque white layer which caused it to $100 \mathrm{k}$ opaque. Two of the vesse1 fragments, Nos. 709 and 592, were more closely related to each other than to the third in that the material embedded in the regions of colorless g1ass was a "shattered" gold foil. These two fragments of typical "gold-band" glass have characteristic shapes that can be identified as being from two of the most commonly encountered vesse 1 forms for this type of ware, a pyxis and a conically shaped flask. The gold-band pyxis, specimen No. 709, was recently excavated at Pompeii (found May 27, 1955 in Region I, block XIV, house 12, Inventory No. 11214) and supplied to us through the courtesy of the Archaeological Services at Pompeii. The gold-band pyramidal flask, specimen No. 592, was of uncertain origin, although it too presumably had been found. in Italy. The object had been purchased in Rome. Justification for its analysis lay in the fact that it so clearly conforms in construction, style and dimensions to a we11-known type. The third multicolored fragment, No. 203, was excavated many miles from Italy at Susa (Find No. 2313 from Stratum $A / N)$. The specimen. was generously supplied by Professor Ghirshman, who described the stratum in which it was found as yielding 1arge1y 1st to 3rd century A.D. objects. In this fragment the regions containing colorless glass include three types, a region with an opaque white layer, another with an opaque yellow layer, and yet another with a double helical spiral of opaque yellow glass. This vesse1 fragment has noticeab1y thinner wa11s than the gold-band fragments, approximately $2 \mathrm{~mm}$ as compared to $4 \mathrm{~mm}$ in thickness. A1so,its color regions are more uniform1y distributed into rough1y paralle1 bands, and this fragment does not contain a reddish violet zone as do the others. Despite these few differences the structures of the three pieces are. strikingly similar and, as we shall see, their compositions are even more strikingly similar.

Three color regions from each of these three specimens were analyzed, i.e., the colorless glass, the dark blue glass, and the light blue glass that was from regions appearing green because of an opaque yellow medial layer. In each instance care was taken to avoid the embedded material, only the clear glass being analyzed.

The results of these analyses are given in Table $I$. The fifteen oxides listed $f$ irst in this table are those primarily introduced into the glass mixture from the basic components. That in this instance their levels of concentration have been only slightly affected by the addition of colorants 
Table I

Analyses of Three Multicolored Vessels of Probable First Century A.D. Manufacture (Concentrations in percent of oxide.)

Specimen 709

Gold band Pyxis fragment excavated at Pompeii
Specimen 592

Fragment of pyramidal gold band flask

Colorless Dark blue Light blue Colorless Dark blue Light blue
Specimen 203

Fragment of multicolóred vessel excavated at Susa

Colorless Dark blue Light blue glass glass glass

\section{Concentrations determined by basic components}

\begin{tabular}{|c|c|c|c|c|c|c|c|c|c|c|}
\hline Lithium & $\mathrm{Li}_{2} \mathrm{O}$ & 0.0011 & 0.0012 & $-\cdots$ & 0.0011 & --- & 0.0018 & 0.00085 & 0.0010 & 0.00048 \\
\hline Sodium & $\mathrm{Na}_{2} \mathrm{O}$ & 16.6 & 16.0 & --- & 13.8 & 13.8 & 11.0 & 15.8 & 17.6 & 17.2 \\
\hline Potassium & $\mathrm{K}_{2} \mathrm{O}$ & 0.76 & 0.93 & 0.72 & 0.81 & 0.60 & 0.81 & 0.74 & . $\quad 1.29$ & 1.00 \\
\hline Rubidium & $\mathrm{Rb}_{2} \mathrm{O}$ & 0.0034 & 0.0043 & 0.0026 & $0.0032^{\prime}$ & --- & 0.0048 & 0.0022 & 0.0043 & 0.0031 \\
\hline Magnesium & $\mathrm{MgO}$ & 0.61 & 0.74 & 0.76 & 0.66 & 0.72 & 0.85 & 0.83 & 0.80 & 1.03 \\
\hline Calcium & $\mathrm{CaO}$ & 7.0 & 6.4 & 6.7 & 6.1 & 5.9 & 7.0 & 6.7 & 7.0 & 8.8 \\
\hline Strontium & $\mathrm{SrO}$ & 0.086 & 0.082 & 0.082 & 0.088 & 0.074 & 0.085 & 0.089 & 0.069 & 0.090 \\
\hline Barium & $\mathrm{BaO}$ & 0.023 & 0.0088 & 0.0057 & 0.015 & 0.011 & 0.0084 & 0.015 & 0.010 & 0.0062 \\
\hline Boron & $\mathrm{B}_{2} \mathrm{O}_{3}^{\prime}$ & 0.052 & 0.073 & 0.080 & 0.095 & 0.080 & 0.095 & 0.074 & 0.069 & 0.072 \\
\hline Aluminum & $\mathrm{Al}_{2} \mathrm{O}_{3}$ & 1.93 & 2.1 & 2.3 & 2.1 & 1.94 & 2.6 & 2.0 & 2.2 & 2.5 \\
\hline Phosphorous & $\mathrm{P}_{2} \mathrm{O}_{5}$ & 0.045 & --- & $-\cdots$ & 0.10 & ---- & $-\cdots$ & 0.061 & --- & --- \\
\hline Titanium & $\mathrm{TiO}_{2}$ & 0.060 & 0.058 & 0.053 & 0.050 & 0.051 & 0.050 & 0.047 & 0.054 & 0.057 \\
\hline Vanadium & $\mathrm{v}_{2} \mathrm{O}_{5}$ & 0.001 & 0.004 & 0.001 & 0.002 & 0.003 & 0.002 & 0.003 & 0.003 & 0.004 \\
\hline Chromium & $\mathrm{Cr}_{2} \mathrm{O}_{3}$ & 0.0039 & 0.0026 & --- & 0.0032 & 0.0026 & 0.0029 & 0.0026 & 0.0016 & --- \\
\hline Zirconium & $\mathrm{ZrO}_{2}$ & 0.0066 & 0.0053 & 0.0057 & 0.0054 & 0.0055 & 0.0051 & 0.0050 & 0.0049 & 0.0049 \\
\hline \multicolumn{11}{|c|}{ Concentrations frequently affected by introduction of additives } \\
\hline Manganese & MnO & 0.87 . & 0.68 & 0.31 & 0.82 & 0.79 & 0.35 & 1.25 & 0.70 & 0.69 \\
\hline Iron & $\mathrm{Fe}_{2} \mathrm{O}_{3}$ & 0.35 & 1.53 & 0.84 & 0.31 & 2.3 & 0.46 & 0.38 & 2.4 & 0.44 \\
\hline Cobalt & $\mathrm{CoO}$ & 0.0047 & 0.12 & 0.0056 & 0.0032 & 0.13 & 0.0066 & 0.0049 & 0.15 & 0.0048 \\
\hline Nickel & $\mathrm{NiO}$ & 0.0013 & 0.0025 & 0.0014 & 0.0074 & 0.0037 & 0.0011 & 0.0019 & 0.0039 & 0.0021 \\
\hline Copper & $\mathrm{CuO}$ & 0.023 & 0.061 & 1.56 & 0.013 & 0.17 & 1.69 & 0.012 & 0.16 & 2.1 \\
\hline Zinc & $\mathrm{ZnO}$ & $(<0.015)$ & $(<0.015)$ & $(<0.015)$ & $(<0.015)$ & 0.048 & $(<0.015)$ & $(<0.015)$ & $(<0.015)$ & $(<0.015)$ \\
\hline Silver & $\mathrm{Ag}_{2} \mathrm{O}$ & 0.00057 & 0.00043 & 0.0052 & 0.00055 & 0.00061 & 0.0074 & 0.00073 & 0.00050 & 0.0083 \\
\hline Tin & $\mathrm{SnO}_{2}$ & $(<0.0019)$ & 0.0041 & $0: 28$ & $(<0.0019)$ & 0.011 & 0.24 & $(<0.0019)$ & 0.068 & 0.28 \\
\hline Antimony & $\mathrm{Sb}_{2} \mathrm{O}_{5}$ & 0.048 & $(<0.027)$ & $(<0.027)$ & $(<0.027)$ & $(<0.027)$ & $(<0.027)$ & 0.035 & $(<0.027)$ & $(<0.027)$ \\
\hline Lead & $\mathrm{PbO}$ & 0.020 & 0.036 & 0.63 & 0.0035 & 0.015 & 0.64 & 0.013 & 0.049 & 0.95 \\
\hline Bis muth & $\mathrm{Bi}_{2} \mathrm{O}_{3}$ & $(<0.00088)$ & $(<.0 .00088)$ & $(<0.00088)$ & $(<0.00088)$ & $(<0.00088)$ & $(\div 0.00088)$ & $(<0.00088)$ & 0.0010 & $(<0.00088)$ \\
\hline
\end{tabular}


is readily apparent from comparison of the colorless and colored glasses. It should be noted how similar the basic glass composition is in all three specimens. One expects all Roman glass of this period to have somewhat similar concentrations of these elements. Average normal variation is within a factor of about 1.5. Also, some experimental variation between analyses has been avoided in comparing these particular specimens by deliberately running them together on the same set of spectrographic plates. Even with this in mind, however, the compositional agreement between the basic glass of these three specimens is unusua11y c1ose.

The last eleven oxides listed in Table I are those which we often have found to be components of additives used in antiquity to affect glass properties. These additives were most frequent1y employed to introduce color or opacity or to counteract discoloration in colorless glasses. Let us consider separately the additive picture for each of the different color regions analyzed.

We have found uncolored Roman glass of the first few centuries A.D. to be of four types which can be differentiated upon the basis of their antimony and manganese contents. As has been discussed by us in detail ${ }^{3}$ these elements appear to have been used to oxidize a reduced iron oxide commonly present in the glass and thereby to remove the "bottle green" discoloration which results from this impurity. In glasses in which these elements were not added as decolorants the normal concentrations of antimony or manganese oxides encountered as impurities are of the order of a few hundredths of one percent. In contrast, the additive concentrations are in the range of several tenths of one percent to about three percent. In uncolored glass of the ear1y Roman Imperial centuries we have encountered a small number of specimens containing neither of these decolorants. However, the major portion of our specimens has been somewhat even1y divided among those with on1y additive amounts of antimony, those with only manganese, and those to which both decolorants had been added. Table I shows that the colorless glass in all three vessels contained the order of one percent manganese oxide with only the normal trace impurity concentrations of antimony. The same decolorant thus had been used in the colorlese eections of all three vessels.

Comparison of the analyses of the light blue glasses to those of the colorless glasses reveals that the concentrations of four elements, copper, tin; lead and silver, are many times greater in the light blue glass than in the colorless. Of these the copper alone would be responsible for the blue 
color, but it may be assumed the others were introduced along with the copper. It is to be noted that the relative proportions of these additive elements are the same as those encountered in some Roman bronzes. It would therefore seem highly probable that an oxidized bronze was the colorant of these g1asses. We have encountered several other examples of Roman glass in which it appeared that copper was introduced as bronze. The additive components for these.glasses are compared to those of the copper blue glass regions of the three multicolored vessels in Table II. The similarities among all of them are apparent. However, it is to be noted that the three multicolored vesse1s are more closely related to each other than to most of the other objects. Considerable variation, of course, has been encountered in the composition of Roman bronzes. Also, much Roman glass colored by copper does not have these accompanying components of bronze, so that the use of bronze as a colorant in a11 three multicolored specimens is itself significant.

Table II

Comparison of. Additive Components in Light Blue G1ass of Mu1ticolored Vesse1s to Other Roman Glass in Which the Colorants Have the Proportions of Bronze

Percent concentration

\begin{tabular}{|c|c|c|c|c|c|}
\hline $\begin{array}{l}\text { Specimen } \\
\quad \text { No. }\end{array}$ & Description & $\begin{array}{l}\text { Copper } \\
\text { ruo }\end{array}$ & $\begin{array}{l}\text { Tin } \\
\operatorname{Snn} \\
\end{array}$ & $\begin{array}{l}\text { Lead } \\
\mathrm{Ph} \Omega\end{array}$ & $\begin{array}{l}\text { Silver } \\
\text { AgO }\end{array}$ \\
\hline \multicolumn{6}{|c|}{ "Color-Band" Vesse1s } \\
\hline 709 & Gold band Pyxis from Pompeii & 1.56 & 0,28 & 0.63 & 0.0052 \\
\hline 592 & Gold band pyramidal flask & 1.69 & 0.24 & 0.64 & 0.0074 \\
\hline 203 & Multicolored vessel from Susa & 2.1 & 0.28 & 0.95 & 0.0083 \\
\hline \multicolumn{6}{|c|}{ Other copper-blue Roman glass } \\
\hline 724 & P1ate from Athens agora & 0.69 & 0.12 & 0.59 & 0.0065 \\
\hline 593 & Bow1 with imbedded millefiori & 0.75 & 0.24 & 0.16 & 0.0048 \\
\hline 743 & $\begin{array}{l}\text { Pitcher from valerian tomb beneath } \\
\text { st. Peters in Rome }\end{array}$ & 2.1 & 0.11 & 0.09 & 0.0045 \\
\hline 835 & $\begin{array}{l}\text { Diatretum fragment from the } \\
\text { Mosel1e valley }\end{array}$ & 2.7 & 0.17 & 0.13 & 0.0129 \\
\hline 845 & $\begin{array}{l}\text { Millefiori fragment from palace } \\
\text { of Lucius Verus in Rome }\end{array}$ & 2.0 & 0.29 & 0.88 & 0.0062 \\
\hline
\end{tabular}

In the dark blue glasses of these three vessels seven elements show a similar pattern of enhanced concentration (Table III). Within this pattern 
Table III

Colorant Components of Some Cobalt Blue Glass of the Roman Centuries

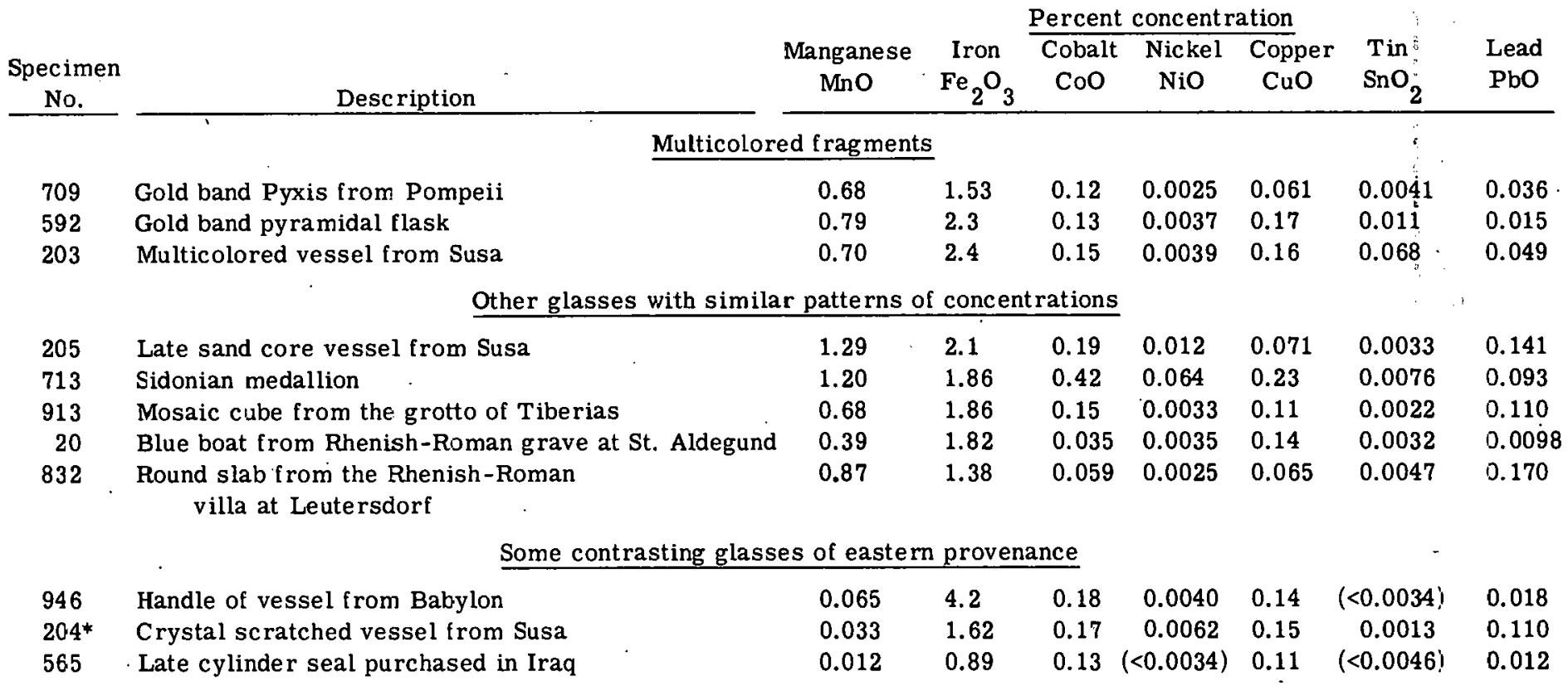

*Also contains $0.37 \%$ zinc oxide. 
is a concentration of cobalt sufficiently great to be primarily responsible for the color. We have also observed several other cobalt-blue glasses of rough1y this same chronological period which have a rather similar concentration pattern of these same elements. This coincidence causes one to speculate whether a common cobalt source, say a particular ore deposit or region of deposits, supplied the colorant for all these specimens. Most of these similar specimens came from relatively western sites. In contrast to this coincidence we have found that several of our cobalt-blue specimens from Mesopotamia and southwestern I ran have had a distinctively different concentration pattern for these elements, one particularly characterized by a very low concentration of manganese. This is a relatively unusual occurrence in cobalt ores, but is characteristic of some arsenical cobalt ores found in Iran and some other sites in the Middle East. ${ }^{4,5}$

Concentrations of the seven indicative elements in the three multicolored vessels, in the other specimens with a similar pattern for these elements and in some Eastern specimens with a contrasting pattern are 1 isted in Table III. In comparing these data it is again noticeable how unusually similar the three multicolored vessels are.

There are, therefore, many points of similarity among these three multicolored fragments: 1) their characteristic layered structure, 2) the basic glass composition, 3) the nature and concentration of the manganese decolorant used in the colorless glass, 4) the use of concentrations of a similar bronze oxidation product in the 1 ight blue region, and 5) the use of like concentrations of the same type of cobalt material to color the dark blue regions. The points of similarity are sufficiently extensive to sustain serious consideration of a common origin for all three objects, even of the possibility that they may have been the product of a single factory or g1ass making community. It would also seem likely that they were made during a narrow period in time. One might consider whether the similarity in composition could have resulted from glass ingots being manufactured at and distributed from a single site for use in the fabrication of these vesse1s at other scattered locations. If this were the case for these very sophisticatedly constructed vesse1s, the duplication of their complex structures at more than one manufacturing site would surely have required the exportation of knowledge of a highly expert skill along with the ingots. However, a widespread commerce in finished objects of this type would seem to be more 
probable. The similarity of these three objects also would suggest that the manufacture of gold-band glass was accompanied by the production of similar multicolored ware that did not contain the characteristic shattered gold foil. One speculates, of course, as to whether most or perhaps all other objects of this specific type would be found to be similarly related. The analysis of but three objects at best only raises this question. It is to be hoped that more specimens of this kind will be analyzed to test the generality of these observations.

Similarities in New Kingdon and Mycenaean Glass

Another instance in which both the basic glass and colorant composition pattern show significant similarities is encountered in the New Kingdom Egyptian and Mycenaean Greek cobalt-blue glasses. Table IV lists the analyses of some Mycenaean rosette plaques and some dark blue glass portions of New Kingdom sand core amphoras. Both sets of objects are stylistically characteristic of the regions in which they were found. However, their compositions are remarkably similar. The specimens analyzed include two New Kingdom amphoras, Nos. 554 and 556, which were excavated at the palace of Amenhotep III at Thebes. They were provided through the generosity of the Brook1yn Museum and Mr. John D. Cooney. Specimen 226 is a Mycenaean ornament from the collection of the National Museum at Athens, Accession No. 2912 (T70), which we obtained through the kind assistance of Mrs. Gladys Weinberg. The British Museum generously furnished Specimens 864 . and 865 which were also Mycenaean ornaments. Specimen 864 is identified with British Museum. No. 70.10.8.59 and is from Ialysus on Rhodes. Specimen 865 has no accession number but is thought also to be from Ialysus.

It should be noted that the basic composition of these glasses is significantly different from that of the Roman glass just considered. In particular, the concentrations of magnesium and potassium are several times greater in these second millennium B.C. glasses than in Roman glass. This is also true of second millennium B.C. glass found in Crete, Anatolia, Mesopotamia and southwestern Iran. This magnesium-potassium rich glass represents one of the basic glass types we have mentioned. ${ }^{1,2}$ We will outline briefly its occurrence pattern because it will be pertinent to some of our following comments. After the second millennium B.C., in specimens from sites west of the Euphrates valley, more specifically in Western glass datable from the middle of the first millennium B.C. until the early Islamic centuries, 
Table IV

New Kingdom Egyptian and Mycenaean Greek Cobalt Blue Glass

\begin{tabular}{|c|c|c|c|c|c|c|}
\hline \multirow{2}{*}{\multicolumn{2}{|c|}{ Specimen number }} & \multicolumn{2}{|c|}{$\begin{array}{c}\text { New Kingdom sand } \\
\text { core amphoras } \\
\end{array}$} & \multicolumn{3}{|c|}{ Mycenaean rosettes } \\
\hline & & 554 & 556 & 226 & 864 & 865 \\
\hline & & \multicolumn{5}{|c|}{ Basic components } \\
\hline Lithium & $\mathrm{Li}_{2} \mathrm{O}$ & 0.0014 & 0.0012 & 0.0021 & 0.0023 & 0.0018 \\
\hline Sodium. & $\mathrm{Na}_{2} \mathrm{O}$ & 20.0 & $\cdot 19.1$ & 12.9 & 13.5 & 16.2 \\
\hline Potassium & $\mathrm{K}_{2} \mathrm{O}$ & 1.07 & 0.98 & 1.17 & 1.51 & 0.56 \\
\hline Rubidium & $\mathrm{Rb}_{2} \mathrm{O}$ & 0.00110 & 0.00078 & 0.0010 & 0.0017 & 0.0013 \\
\hline Magnesium & $\mathrm{MgO}$ & 5.0 & 3.9 & 3.8 & 5.8 & 4.1 \\
\hline Calcium & $\mathrm{CaO}$ & 7.7 & 7.5 & 7.1 & 9.9 & 8.8 \\
\hline Strontium & $\mathrm{SrO}$ & 0.21 & 0.15 & 0.100 & 0.089 & 0.071 \\
\hline Barium & $\mathrm{BaO}$ & 0.0024 & 0.0013 & 0.0017 & 0.0046 & 0.0023 \\
\hline Bürüin & $\mathrm{B}_{2} \mathrm{O}_{3}$ & 0.049 & 0.001 & 0.068 & 0.081 & 0.170 \\
\hline Aluminum & $\mathrm{Al}_{2} \mathrm{O}_{3}$ & 2.8 & 1.95 & 2.1 & 3.2 & 2.8 \\
\hline Phosphorous & $\mathrm{P}_{2} \mathrm{O}_{5}$ & 0.14 & 0.13 & 0.051 & $0.158^{\circ}$ & 0.060 \\
\hline Titanium & $\mathrm{TiO}_{2}$ & 0.085 & 0.092 & 0.133 & 0.21 & 0.162 \\
\hline Vanadium & $\mathrm{V}_{2} \mathrm{O}_{5}$ & 0.020 & 0.016 & 0.011 & 0.032 & 0.019 \\
\hline Chromium & $\mathrm{Cr}_{2} \mathrm{O}_{3}$ & 0.0017 & 0.0017 & 0.0018 & 0.0027 & 0.0012 \\
\hline \multirow[t]{2}{*}{ Zirconium } & $\mathrm{ZrO}_{2}$ & 0.0098 & 0.0098 & 0.0110 & 0.0129 & 0.0110 \\
\hline & & \multicolumn{5}{|c|}{ Usual additive components } \\
\hline Manganese & $\mathrm{MnO}$ & $\underline{0.41}$ & 0.21 & 0.24 & 0.35 & 0.42 \\
\hline Iron & $\mathrm{Fe}_{2} \mathrm{O}_{3}$ & 0.52 & 0.58 & 0.93 & 1.62 & 1.15 \\
\hline Cobalt & $\mathrm{CoO}$ & $\underline{0.22}$ & $\underline{0.11}$ & $\underline{0.079}$ & $\underline{0.12}$ & $0.1 \%$ \\
\hline Nickel & $\mathrm{NiO}$ & 0.141 & 0.050 & 0.041 & $\underline{0.068}$ & 0.083 \\
\hline Copper & $\mathrm{CuO}$ & 0.019 & 0.076 & 0.052 & 0.091 & $\underline{0.182}$ \\
\hline Zint: & $\mathrm{ZnO}^{-}$ & $\underline{0.30}$ & $\underline{0.12}$ & $\underline{0.12}$ & $\underline{0.14}$ & $\underline{0.14}$ \\
\hline Silver & AgO & 0.00032 & 0.00120 & 0.00023 & $(<0.00038)$ & $(<0.00038)$ \\
\hline Tin & $\mathrm{SnO}_{2}$ & $(<0.0025)$ & 0.0012 & 0.0046 & $(<0.0032)$ & 0.0027 \\
\hline Antimony & $\mathrm{Sb}_{2} \mathrm{O}_{5}$ & $\underline{0.42^{*}}$ & 0.063 & 0.039 & 0.078 & $(<0.046)$ \\
\hline Lead & $\mathbf{P b O}$ & 0.0033 & $\underline{0.120}$ & 0.0019 & 0.0043 & $(<0.0046)$ \\
\hline Bismuth & $\mathrm{Bi}_{2} \mathrm{O}_{3}$ & 0.0013 & $(<0.0010)$ & $(<0.0013)$ & $(<0.0015)$ & $(<0.0015)$ \\
\hline
\end{tabular}

*Probable separate additive. Opaque glass. 
one virtually ceases to encounter glass of the high magnesium-potassium type. At the same time rough1y ha1f or more of our specimens of this period from the Tigris valley and eastward have had this composition. Other data in the 1 iterature indicate the persistence of this glass type we 11 into Central Asia. ${ }^{6-8}$ The second millennium B.C. tradition of glassmaking was obviously continued in these more eastern regions. In the ear1y Islamic centuries glass of this composition was again widely intruduced into such relatively western regions as Egypt, Palestine and Syria in objects of Islamic manufacture.

The group of additive oxides at the bottom of Table IV shows that not only do the Mycenaean and New Kingdom glasses have similar basic composition but that these dark blue glasses were colored with a like cobalt containing material. The concentrations of oxides which are significantly greater than customarily encountered in colorless glass of this period have been underlined. The pattern of constituents accompanying cobalt in these specimens is distinctly different from that of the later Roman and Eastern glasses just described. A most interesting characteristic of this cobalt additive is a significant concentration of zinc, an element which has been observed only rare1y in ancient glass. The coincidence that both the same basic glass and the same cobalt material were used in the Mycenaean and New Kingdom glasses strongly indicates a commerce between widely separated regions in glassmaking materials or perhaps even in glass itself. in the form of ingots. Since the early Greek g1ass rosettes are common1y encountered on $1 \mathrm{y}$ in areas of pronounced Mycenaean cultural influence, a commerce in glass ingots, which could be local1y reformed, would in this instance seem more probable than a commerce in finished objects.

Among the second millennium B.C. glasses from Mesopotamia that have been analyzed only one specimen colored by cobalt has been encountered. It was a lump of blue glass, thought to be a factory fragment, found at Eridu, the analysis of which was published by Garner. ${ }^{4}$ This specimen was similar in basic composition to the early Greek and Egyptian glass. However, 1ike the other Central $\Lambda$ sian glasses we have mentioned, its cobalt was unaccompanied, by manganese. It would seem that the manganese-free arsenical cobalt ores of the Middle East were exploited there for several millennia and also that cobalt from some other source was employed in the early glass of Egypt and Mycenae. The source of supply of cobalt in ancient Egypt has been a mystery because only trace amounts of this element have been found in ores there. It is to be 
hoped that the pattern of accompanying elements observed in these glasses, particular1y the significant1y high zinc concentration, will he1p eventual1y in the tracing of this source.

Contrasts between Glass Found at Begram and Other Central Asian Finds

During the early centuries of Imperial Rome the direct over1and trade routes from the Far East to the Roman Empire were frequently impeded by a hostile Parthia. To avoid this interference an a1ternate trade route turned off at Bactra, a major metropolis east of the Parthian frontier, leading south and east through modern Afghanistan, Pakistan and northern India to ports on the Indian Ocean from which goods from the Orient could be shipped to Egypt and the Mediterranean. Two sites on this alternate southern trade route have been extensively excavated, Begram, north of Kabul in Afghanistan, and Taxila, on the Punjab-Pakistan border. Sizable quantities of glass have been found at both sites.

Eight specimens of glass from Taxila were analyzed by $S$. U11ah and reported by Y. P. Varshney. ${ }^{6}$ The specimens, we re not we 11 dated and could. have ranged from the 4 th century B.C. until the 6 th century A.D. with dates toward the middle of this period being more probable: The specimens are not ful1y compositionally consistent but, in the main, they comprise a variation of the magnesium-potassium rich g1 ass which we associate during this period only with Eastern finds. In some of these specimens the potassium concentration, is unusually high, although sodium oxide remains the principal alkali. A group of glass specimens of very similar composition was excavated at Shamshir Ghar, an inhabited cave site in Kandahar province, Afghanistan. They were analyzed spectrographically by R. H. C1ose and H. C. Ross and reported by $R$. W. Smith. ${ }^{7}$ These sperimens ranged in date throughout the first millennium A.D., including specimens of the Kushan, Sassanian and early Islamic periods. Recently Abdurazakov and Bezborodov ${ }^{8}$ have published an extensive study of the composition of medieval glasses from Central Asia. These specimens were all of later date than the Taxila glass; they range in time from the, 8 th through the 14th centuries. They are very similar in composition to the Taxila specimens, however, and indicate a continued association of this $t y p e$ of glass with this region. The averages of the Taxila glass, the Shamshir Ghar glass and the medieval Central Asian glass are compared in Table V. An opaque red glass, which as is usual for its type contained a high lead concentration, was not included in the averages of the 
Table V

Comparison of Glass From Taxila, Shamshir Ghar, and Various Medieval Glasses From Central Asia

\begin{tabular}{|c|c|c|c|c|}
\hline \multicolumn{2}{|c|}{ Site of find } & $\operatorname{Taxila} \mathrm{a}^{\mathrm{a}}$ & Shamshir Ghar ${ }^{b}$ & Central Asian USSR \\
\hline Numbe & of specimens & .7 & 17 & 22 \\
\hline Sodium & $\mathrm{Na}_{2} \mathrm{O}$ & 17.2 & 12 & 14.89 \\
\hline Potassium & $\mathrm{K}_{2} \mathrm{O}$ & 2.61 & 5 & 3.25 \\
\hline Magnesium & MgO & 2.74 & 7 & 4.25 \\
\hline Ca1cium & $\mathrm{CaO}$ & 6.26 & 5 & 7.28 \\
\hline A1uminum & $\mathrm{A}_{2} \mathrm{O}_{3}$ & 2.89 & 7 & 1.99 \\
\hline Manganese & Mno & 0.10 & 0.1 & 0.66 \\
\hline Iron & $\mathrm{Fe}_{2} \mathrm{O}_{3}$ & 1.58 & 6 & 0.83 \\
\hline Silicon & $\mathrm{SiO}_{2}$ & 65.81 & 50 & 66.67 \\
\hline
\end{tabular}

Taxila glasses. The Shamshir Ghar glass was analyzed by a spectrographic method of admittedly only approximate accuracy; the data were 1 isted to but one significant figure. Considering this uncertainty in analysis, the three sets of data show good agreement. This correlation between the Taxila glass and other glass of a Central Asian provenance, coupled with the fact that the Taxila specimens are fundamentally related to the magnesium-potassium rich glass which is almost never found in objects of the same period from sites west of the Euphrates, provides strong evidence that most of the se Taxila specimens were of Eastern manufacture. On1y one of the eight specimens analyzed by Ullah had a composition approaching that of western "Roman" glass. An Eastern origin for this glass is also consistent with the fact that ve ry few artifacts of Mediterranean origin have been found at Taxila.

In contrast, at Begram a veritable hoard of fine objects of Mediterranean manufacture was found stored together with many equally fine Oriental objects in what appear to be two storage rooms of a "palace." Ghirshman has proposed a terminal date for the occupation period to which the "palace" belongs of about $250 \mathrm{~A} . \mathrm{D}$., the time of the conquest of this territory by the Sassanid king Shapur I. The coins and artifacts in this collection, including the glass, 
range in type from the 1st to the 3rd centuries, indicating that the hoard represented the collection of a considerable period.

We have been privileged to analyze eight specimens of glass from Begram which were supplied to us through the courtesy. of Dr. Schlumberger. The specimens include a minute fragment of the Begram diatretum, a beautiful colorless glass vessel upon whose outer walls representations of ships and a lighthouse have been carved with such deep undercutting that they were almost free-standing. The lighthouse has been identified by H. Seyrig with the pharos of Alexandria. The analyses of these specimens are 1 isted in Table VI. The compositions were all of the low magnesium and potassium type which we associate with western specimens and which contrasts significantly with the Central Asian glasses just described. The uncolored glasses were all decolorized solely with antimony, a technique which we have quite frequent1y encountered in Western glass of about the 2nd century A.D. Table VII compares means of the Begram analyses with mean compositions of groups of similar glasses, decolorized by antimony, which were found in various regions throughout the Roman Empire. The agreement between them is very close with the exception of the lead concentrations. In the case of lead the simple blown vesse1s from Begram have close to the same lead concentrations as their counterparts from Western sites, but the painted glasses show an enhanced lead concentration and the deeply cut objects, such as the diatretum, yet a higher concentration. It should be noted, however, that some other deeply cut objects of basically Roman composition with the same relatively high lead concentrations, also decolorized by antimony, have been found at more western sites. Most notable among such specimens is the diatretum now in the treasury of San Marco in Venice, which was taken from Constantinople in the sack of 1204 A.D. The high lead concentrations may be more characteristic of a particular type of object than of the region in which such objects have been found.

Two of the Begram specimens contained g1ass colored blue by means of cobalt. The accompanying impurities in these cobalt-blue glasses are closely similar to those found in the more western "Roman" specimens which we have discussed and 1isted in Table III. The larger concentrations in the blue glass compared to those in the colorless are 1isted in Table VIII, where they are compared to the means of similar concentrations in the Western glasses. In constrast to this it has been a common experience to encounter Central Asian 
Table VI

Glass From Beg ram

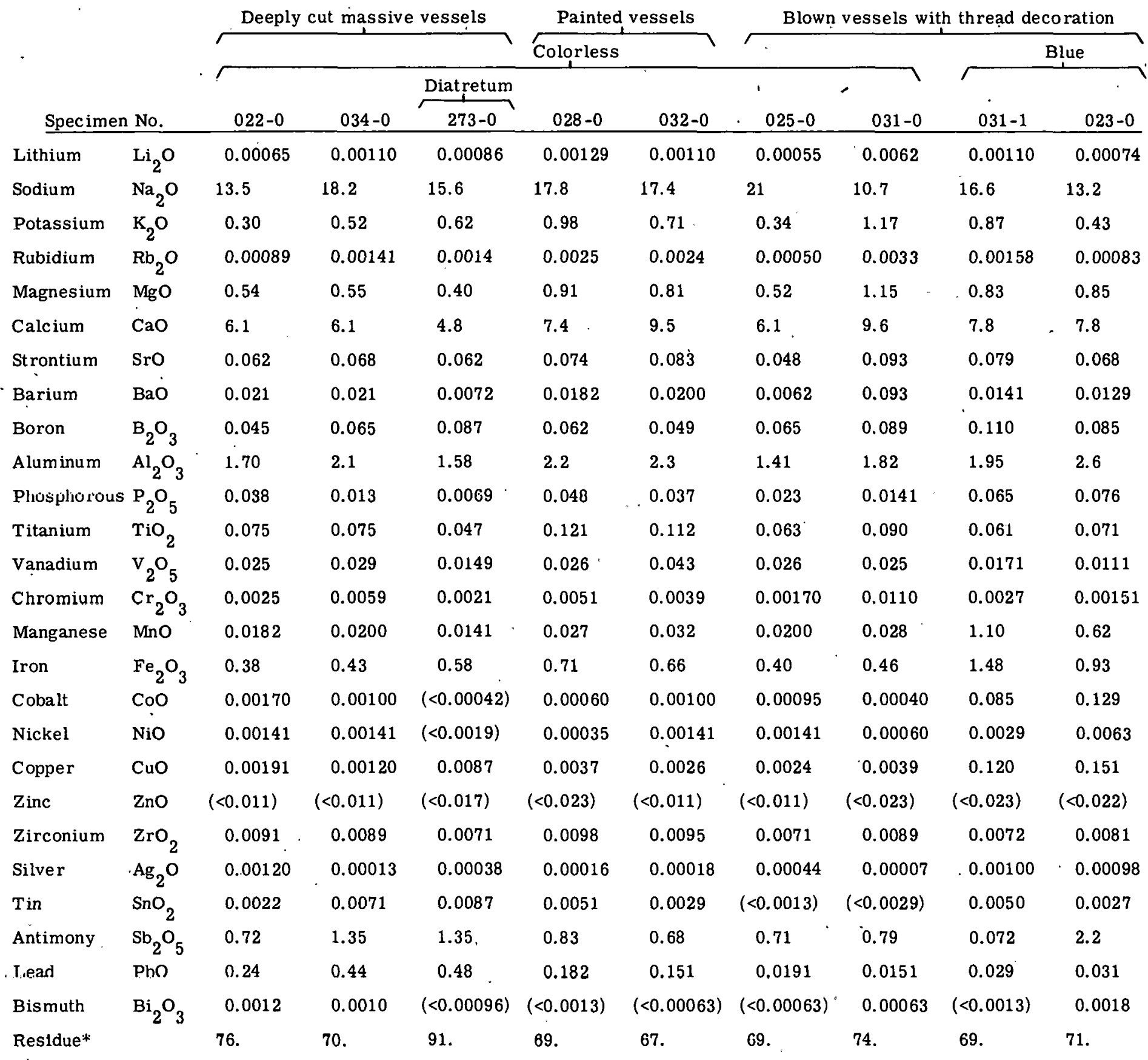


Table VII

Correlation Between Begram Glass and Roman Glass

Decolorized by Antimony From Eastern Mediteranean, Italian, and Rhenish Sites

\section{(Mean concentrations - percent oxide.)}

\begin{tabular}{|c|c|c|c|c|c|c|c|}
\hline & . & , & $\begin{array}{c}\text { Begram } \\
\text { specimens }\end{array}$ & $\begin{array}{r}\text { Specimens f } \\
\text { Egypt, Syr } \\
\text { Anatolia, } \\
\text { Greece }\end{array}$ & $\begin{array}{l}\text { from } \\
\text { ria, } \\
\text { and }\end{array}$ & $\begin{array}{l}\text { Specimens } \\
\text { from Italy }\end{array}$ & $\begin{array}{l}\text { Spccimcns } \\
\text { from Roman } \\
\text { 'Rhineland }\end{array}$ \\
\hline Number o & of specim & nens & 9 & 7 & & 6 & 6 \\
\hline Lithium - & $\mathrm{Li}_{2} \mathrm{O}$ & & 0.0011 & 0.00058 & & 0.00084 & 0.0012 \\
\hline Sodium & $\mathrm{Na}_{2} \mathrm{O}$ & & 15.7 & 14.9 & & 17.6 & 16.5 \\
\hline Potassium & $\mathrm{K}_{2} \mathrm{O}$ & & 0.60 & 0.48 & & 0.41 & 0.56 \\
\hline Rubidium & $\mathrm{Rb}_{2} \mathrm{O}$ & & 0.0014 & 0.00097 & & 0.0010 & 0.0017 \\
\hline Magnesium & $\mathrm{MgO}$ & & 0.69 & 0.84 & & 0.82 & 0.97 \\
\hline Calcium & $\mathrm{CaO}$ & & 7.1 & 6.5 & & 7.4 & 7.8 \\
\hline St rontium & SrO & & 0.070 & 0.076 & & 0.074 & 0.063 \\
\hline Barium & $\mathrm{BaO}$ & & 0.017 & 0.011 & & 0.0095 & 0.0069 \\
\hline Boron & $\mathrm{B}_{2} \mathrm{O}_{3}$ & & 0.070 & 0.092 & & 0.104 & 0.087 \\
\hline Aluminum. & $\mathrm{Al}_{2} \mathrm{O}_{3}$ & & 1.93 & 2.3 & & 2.1 & 2.1 \\
\hline Phosphorous & $\mathrm{P}_{2} \mathrm{O}_{5}$ & & 0.024 & 0.023 & & 0.026 & 0.096 \\
\hline Titanium & $\mathrm{TiO}_{2}$ & & 0.077 & 0.097 & & 0.115 & 0.103 \\
\hline Vanadium & $\mathrm{V}_{2} \mathrm{O}_{5}$ & & 0.023 & 0.007 & & 0.026 & 0.019 \\
\hline Chromium & $\mathrm{Cr}_{2} \mathrm{O}_{3}$ & & 0.0033 & 0.0022 & & 0.0022 . & 0.0020 \\
\hline Manganese & $\mathrm{MnO}$ & & $0.022^{*}$ & 0.026 & & 0.020 & 0.043 \\
\hline Iron & $\mathrm{Fo}_{2} \mathrm{O}_{3}$ & & $0.50^{*}$ & 0.52 & & 0.66 & 0.58 \\
\hline Cobalt & $\mathrm{CoO}$ & & $0.00070^{*}$ & 0.00075 & & 0.00031 & 0.00045 \\
\hline Nickel & $\mathrm{NiO}$ & . & $0.00097^{*}$ & 0.0015 & & 0.0011 & 0.0013 \\
\hline Copper & $\mathrm{CuO}$ & & $0.0029^{*}$ & 0.0061 & & 0.0030 & 0.0055 \\
\hline Zinc & $\mathrm{ZnO}$ & & $(<0.02)$ & $(<0.02)$ & & $(<0.02)$ & $(<0.02)$ \\
\hline Zirconium & $\mathrm{ZrO}_{2}$ & & 0.0084 & 0.0083 & & 0.0106 & 0.0079 \\
\hline Silver & $\mathrm{AgO}$ & & $0.00025^{*}$ & 0.00036 & & 0.00016 & 0.00027 \\
\hline$T$ in & $\mathrm{SnO}_{2}$ & & $0.0029^{*}$ & 0.0011 & & 0.0010 & 0.00092 \\
\hline Antimony & $\mathrm{Sb}_{2} \mathrm{O}_{5}$ & . . & 0.74 & 0.61 & & 0.85 & 0.56 \\
\hline Lend & $\mathrm{PbO}$ & . & $0.080^{* *}$ & 0.0060 & & 0.0030 & 0.0050 \\
\hline Bismuth & $\mathrm{Bi}_{2} \mathrm{O}_{3}$ & . & $(<0.001)$ & $(<0.001)$ & $\therefore$ & $(<0.001)$ & $(<0.001)$ \\
\hline
\end{tabular}


Table VIII

Comparison of Colorant Components in Coba1t-Blue Glass

from Begram and in Similar Western Glass

\begin{tabular}{cccccccc}
$\begin{array}{c}\text { Specimen } \\
\text { No. }\end{array}$ & $\begin{array}{c}\text { Manganese } \\
\text { MnO }\end{array}$ & $\begin{array}{c}\text { Iron } \\
\mathrm{Fe}_{2} \mathrm{O}_{3}\end{array}$ & $\begin{array}{c}\text { Percent } \\
\text { Cobalt } \\
\mathrm{CoO}\end{array}$ & $\begin{array}{c}\text { Nicke1 } \\
\text { NiO }\end{array}$ & $\begin{array}{c}\text { Copper } \\
\text { CuO }\end{array}$ & $\begin{array}{c}\text { Tin } \\
\mathrm{SnO}_{2}\end{array}$ & $\begin{array}{l}\text { Lead } \\
\mathrm{PbO}\end{array}$ \\
\cline { 3 - 7 } $31-1$ & 1.10 & 1.48 & 0.085 & 0.0029 & 0.120 & 0.0050 & 0.029 \\
23 & 0.62 & 0.93 & 0.129 & 0.0063 & 0.151 & 0.0027 & 0.031
\end{tabular}

Mean concentration in eight similarly colored western specimens
0.86
1.88
0.125
0.0054
0.110
0.0063
0.053

cobalt-blue glasses and glazes colored with the manganese-free cobalt of the Middle Eastern ores. Thus we observe that in both their basic composition and in their cobalt color chemistry the Begram specimens differ from most Central Asian glass, particularly that at neighboring Taxila, but are similar to contemporary Western glass. Although there is always a possibility that Western techniques and raw materials could have been introduced into Central Asia, these observations rather strongly suggest a Western origin for this glass.

\section{The Sacro Catino}

A most outstanding possession of the treasury of the Cathedral of San Lorenzo in Genoa is a beautiful green cut glass bow1 which was brought to Genoa at the beginning of the 12 th century after having been taken in the sack of Caesarea. Since this time the vessel has been held in reverence and given the name Sacro Catino in the belief that it was used by Christ at the Last Supper. The bow1 a1so was believed at one time to have been carved from a single emerald. However, it was taken from Genoa by Napoleon and was returned from France broken. The conchoidal fractures revealed it to be glass.

'We have very graciously been allowed to analyze a minute but adequate. specimen of this vesse1. The specimen was but three milligrams of glass from an inconspicuous portion of the bow1. Prepared for analysis, the finely divided specimen was spread out evenly upon a special adhesive film and analyzed rondestructively by means of $X$-ray fluorescence for those elements 
that most significantly characterize it as to type. The results of this analysis are given in Table IX where the data are compared to the mean concentrations of the same elements in high magnesium-potassium and $10 \mathrm{w}$ magnesium-potassium categories of glass. The concentrations of magnesium and potassium oxides in the glass of the Sacro Catino quite definite1y characterize it as being the high magnesium-potassium type. The bowl also contains manganese in an additive concentration leve1 which is often encountered in either type of glass. The slightly higher than average concentration of lead in this bow1 is not unusual for deliberately colored glass.

Tab1e IX

Comparison of Sacro Catino Composition to those of Basic Categories of Ancient Glass

\begin{tabular}{|c|c|c|c|c|c|}
\hline \multirow[b]{2}{*}{ Description } & \multirow[b]{2}{*}{$\begin{array}{c}\text { Magnesium } \\
\text { MgO }\end{array}$} & \multicolumn{3}{|c|}{ Percent concentration } & \multirow[b]{2}{*}{$\begin{array}{l}\text { Lead } \\
\text { PbO }\end{array}$} \\
\hline & & $\begin{array}{c}\text { Potassium } \\
\mathrm{K}_{2} \mathrm{O} \\
\end{array}$ & $\begin{array}{c}\text { Manganese } \\
\text { Mno }\end{array}$ & $\begin{array}{c}\text { Ant imony } \\
\mathrm{Sb}_{2} \mathrm{O}_{3} \\
\end{array}$ & \\
\hline Sacro Catino & 5.1 & 1.8 & 0.28 & 0.022 & $0.054^{\circ}$ \\
\hline $\begin{array}{l}\text { Mean of high } \\
\text { magnesium-potassium } \\
\text { g1asses }\end{array}$ & 4.7 & 1.53 & 0.25 & $0.026^{\mathrm{b}}$ & 0.010 \\
\hline $\begin{array}{l}\text { Mean of } 1 \text { ow } \\
\text { magnesium-potassium } \\
\text { glasses }\end{array}$ & 1.0 & 0.43 & 0.24 & $0.030^{b}$ & 0.016 \\
\hline $\begin{array}{l}\text { It is like1y the high } \\
\text { used in this bowl. } \\
\text { b Means for specimens } w\end{array}$ & $\begin{array}{l}\text { h lead con } \\
\text { without ad }\end{array}$ & $\begin{array}{l}\text { ntration a } \\
\text { tive amoun }\end{array}$ & $\begin{array}{l}\text { ses from the } \\
\text { of antimony. }\end{array}$ & green $\operatorname{col}$ & rant \\
\hline
\end{tabular}

We have already mentioned the fact that we believe glass of this type was manufactured at the time of Christ in Eastern regions that were approximately bounded on the west by the Tigris river valley and the eastern reaches of the Euphrates. The occurrence of glass of this type at sites west of this area has been very rare. In fact out of approximately two hundred analyses of ancient glass specimens datable to the centuries of Roman pre-eminence and relatable to sites within the ultimate boundaries of the Roman Empire we have encountered only one specimen, disregarding for the moment the Sacro Catino, with this high magnesium-potassium composition. This unusual 
specimen was found in a second century A.D. grave in the Roman cemetery upon the Vatican Hill in Rome. The grave was among those discovered during excavation of a garage foundation within the grounds of the papal state. The composition of this fragment is so exceptional for its circumstances of find that it seems likely it would have been an imported object.

One might 1 ikewise argue that the Sacro Catino was an imported object. In fact our data indicate specifically that the Sacro Catino could have been an object of the time of Christ. Over-a11 considerations, however, indicate it is considerably more 1ikely that it was of much later manufacture. We have mentioned in previous sections that glass of the Sacro Catino composition typified the production of early Islamic glass. By about the tenth century A.D. this magnesium-potassium rich Is1amic glass would have become the g1ass predominantly encountered in the Palestinian area. Thus, although the Sacro Catino composition would have been most unexpected in a Palestinian object of the first century, it would have been the likely composition of an object from this area of the early Islamic centuries. This double consideration, coupled with the fact that our collaborator ${ }^{9}$ considers the sacro Catino to be Islamic in design, makes it seem rather probable that the bowl was fabricated at most a few centuries before it was captured at Caesarea in 1101.

A Group of Egyptian Glasses Characterized by Low Calcium Concentrations

The basic compositions of most ancient glasses conform remarkably. closely to the few categories that have been described. In fact the occurrence of each of the basic compositional types in many distant1y separated geographic regions over many centuries leads us to conclude that the differences between these categories arise from a fundamental difference in the kind of raw materials used to produce them, rather than from geographic variations in the composition of a given raw material. In a very few instances, however, a rather substantial and consistent variation in a basic composition has been observed to be associated with a particular geographic region. We have mentioned as an example of this the special Central Asian formulation which is basically like the magnesium-potassium rich glass encountered at more western sites, except that many Central. Asian specimens have even more potassium than is normally encountered elsewhere. It would seem likely that a similar alkali was used in the Central Asian and more western magnesiumpotassium rich glasses but that this component as encountered in the Centra1 Asian region contained an enhanced amount of potassium. 
We have observed an analogous phenomenon among our low magnesiumpotassium glasses. A group of ten specimens, a11 of which can be direct1y associated with Egypt, has been found to contain only about half the usual calcium concentration for its compositional type. In other respects they do not show as a group significant deviation from the normal pattern for low magnesium-potassium glass. These specimens are 1 isted in Table $\mathrm{X}$ in what may be rough1y chronological order. They include a glass in1ay, Brook1yn Museum

Tab1e X

Pattern of Low Calcium Concentrations in Low-Magnesia G1asses from Egypt

Spec-

imen

No.

820

785

786.

668

324

326

671

715

961 Percent concentration

Magnesium Calcium

Ratio

Description

Blue-green inlay from reign of Ptolemy V (205-180 B.C.)

0.81

3.8

4.7

Roman fragments excavated at the palace of Amenhotep III

(uncertain date)

0.94

3.7

3.9

1.01

4.9

4.8

1.06

4.2

4.0

Egyptian weight (101 $\mathrm{AH}=719 / 20 \mathrm{~A} . \mathrm{D}$.

0.92

2.9

3.1

1.36

4.5

3.3

1.26

3.5

2.8

1.39

3.1

2.2

Glass from ancient kiln at Wadi Natrun (uncertain date)

1.35

3.8

2.8

Chalice from Wadi Natrun

1.15

2.6

2.3

Means

1.11

3.6

3.3

Mean values of 120 low magnesium g1asses from Near Eastern sites

0.98

6.97

7.11

specimen 604, Syrian glass weight of the Walters Art Ga1lery

0.79

5.8

7.4

No. 33.383, attributed by John D. Cooney to the reign of Ptolemy V, 205-180 B.C., and furnished to us through the courtesy of Mr. Cooney and the Brook1yn Museum; three fragments of what appear to be Roman glass which were found at the site of the Palace of Amenhotep III at Thebes during the Metropolitan Museum of Art excavations of 1910-12 and were lent to us by that Museum; four Egyptian glass weights with inscriptions dating them to the 8 th century A.D. Two of these specimens, Nos. 324 and 326, were supp1ied by Dr. George Miles 
and the American Numismatic Society and two, Nos. 668 and 671, we re from the Ray W. Smith collection. Attributions of all four weights were kindly provided by Dr. Miles. An amorphous glass lump from a kiln at an ancient glass factory in the Wadi Natrun was supplied to us by. Dr. Zaki Iskander, and a fragment of a chalice which was discovered in a sealed room in a coptic monastery in the Wadi Natrun was generous1y lent to us for study by the Metropolitan Museum.

The inclusion of an ancient factory fragment from the Wadi Natrun among these unusual specimens provides some presumption that they we re a11 made in this region. It would seem particularly likely that the Coptic chalice discovered in a Wadi Natrun monastery was 1ocal1y manufactured. The 8 th century glass weights and the specimens from Wadi Natrun show both more close correlation among themselves and greater deviation from the norm of 10 w magnesium-potassium g1ass than the earlier specimens.

We have analyzed in all thirteen Arabic glass weights. These weights are most interesting and valuable specimens because, as a rule, they had.been stamped with raised inscriptions while the glass was still soft at the time of manufacture. These inscriptions frequent1y include references to the government official who had ordered their production and sometimes to the reigning Caliph. The inscriptions serve both to date the weights and to indicate their region of origin.

The references on most such weights have been to Egyptian officials. However, Ettinghausen ${ }^{10}$ has published an Umaiyad pound weight in the collection of the Walters Art Gallery whose inscription bears reference both to a Caliph, Yazīd III, who reigned only during the year $744 \mathrm{A.D}$. , and also to the man known to have been the financial director of the treasury in Damascus at that time, a1-Walīd ibn 'Abd al-Rahmān. At this same time the financial director in Egypt is known to have been 'I $\bar{s} \bar{a}$ ibn $A b \bar{i}$ 'At'. '. This Egyptian official issued weights inscribed with his own name. Dr. Ettinghausen argued that the weight bearing reference to the Syrain official was probably made in Syria. We are very grateful that the Walters Art Gallery has permitted us to sample this weight, our specimen No. 604, and also that among the weights supplied to us by Dr: George Miles is nne bearing the name of the contemporary Egyptian financial director, ' $\bar{I} s \bar{a}$ ibn $A b \bar{i}$ 'At $\bar{a}$ '. It is 1 isted in Table $X$ as specimen 326.

An interesting chronology is apparent in the analysis of our Egyptian glass weight specimens. A11 four 8th century Egyptian weights have had the 
unusual low calcium composition just described. A 9 th century weight in contrast had the standard low magnesium-potassium.composition with a normally high calcium content. One hesitates to draw conclusions from one specimen, but it would be interesting to seek out more 9 th century weights to determine whether this was a consistent chronological change. However this may be, in seven glass weights datable from the 10th century through the Mameluke period there was a consistent dramatic change to the high magnesium-potassium formulation. We have mentioned several times the return of this formulation of glass to the Eastern Mediterranean region in the products of Is1amic manufacturers. These data indicate that in Egyptian glass weights this return occurred at approximately the 10th century. Unfortunately too few of our other early Islamic specimens can be sufficient1y we11-dated to permit us to estimate by what degree of generality this date can be applied to the same change in formulation we have observed in other types of Islamic glass objects from this and other geographic regions.

The analysis of the Walters Art Gallery weight, No. 604, which is datable to 744 A.D., shows that it does not have the characteristically low calcium concentration which has typified all of our 8 th century Egyptian weights and in particular the closely contemporaneous weight, Specimen No. 326. Compared to the average of 120 analyses of near Eastcrn glass specimens of standard low magnesium-potassium composition, the Walters Gallery weight contains just slightly lower than normal concentrations of both magnesium and calcium but pcrfcctly standard ielalive concentrations of these elements. Relative concentrations of related elèments have often provided more consistent correlations than their absolute concentrations. Table $x$ also shows that the calcium magnesium ratio in the low-calcium Egyptian subgroup is consistently low and differs significant1y from the mean for related Near Eastern specimens and from the Walters Gallery weight.

The agreement between the composition of the Walters Gallery weight and that of much Syrian and other near Eastern glass and the contrast betwern it and the composition of contemporaneous Egyptian glass weights do indeed add confirmation to Dr. Ettinghausen's opinion that this weight was of Syrian manufacture.

\section{Conclusion}

It has not been the fundamental purpose of the Brookhaven program to seek out and explore individual studies of archaeological significance such 
as these just described. Rather it has been its purpose in part to lay a groundwork for such studies. It has been gratifying, however, that severa1 such instances have emerged which demonstrate so we11 the type of historical inferences which can be derived from analytical data. There are within our data several other indications of probable association of particular origins with characteristic compositions which would require more extensive investigation to be credib1y established. However, it would seem worthwhile that such promising leads be pointed out for future exploration, and we shall do so in the comprehensive reporting of our data. One hopes and expects that, as the accumulation of analyses of ancient artifacts becomes more comprehensive and the significance of individual analyses increases, it will be possible to derive from them considerable new insight into human technical, cultural, and social history.

Note on Methods of Analysis

Emission spectroscopy, flame photometry, colorimetry and $\mathrm{X}$-ray fluorescence were a11 used in obtaining these data. Sodium was determined by direct flame photometric comparison of ancient glass and National Bureau of Standards specimens. One milligram samples of glass were put into solution and diluted to $100 \mathrm{~m} 1$ for these analyses. Phosphorous was determined by the molybdenum blue colorimetric procedure on solutions prepared from ten milligram specimens of glass. The remaining elements were determined by emission spectroscopy with the exception that a non-destructive $X$-ray fluorescence method was used to analyze the sacro catino.

Two spectrographic procedures were employed. The elements 1 ithium, potassium, rubidium, barium and chromium were determined from 1 ines occurring in the infrared region. To avoid molecular band interference in this region the specimens were arced in a helium atmosphere. Because carbon electrode cups would not burn away in this inert atmosphere, special precautions had to be undertaken to insure complete volatilization of glass specimens during the period of plate exposure. To achieve this special shallow cup electrodes were cut from "amorphous" carbon rods. Because of the relatively high thermal conductance of "amorphous" carbon these electrodes in a D.C. arc of 13 amperes current heated to a sufficient temperature to produce the necessary volitalization. The remaining nineteen elements we re determined from spectrographic lines in the ultraviolet. Glass specimens in specially designed graphite cups 
were ignited in air in an eight ampere D.C. arc until the containing cup had completely burned away.

Ten milligram glass specimens were arced in both spectroscopic procedures. Spectra of standard specimens were included on each plate to provide an exposure-processing factor for the plate. The estimated standard deviation of individual measurements for al1. these procedures does not exceed twenty percent of the determined value. In most instances closer precision was obtained by running at least duplicate analyses. Quantities of samples available did not always permit this, and, in light of the large number of analyses involved in the over-all study, it was not always felt necessary that all specimens in a closely related group be given multiple analys is unless some unusual feature appeared in the first analysis.

The non-destructive analys is of the very smali sacro catino specimen was accomplished by means of a special $\mathrm{X}$-ray fluorescence technique. The effective sample response area for our Nore1co X-ray fluorescence unit was found to be a circle of one centimeter diameter. If an excess of finely powdered glass was brushed over such an area. of a plastic adhesive film, such as Minnesota Mining and Manufacturing Co. Scotch Brand Polyester Film Tape No. -850 , a maximum of a few milligrams of the glass would adhe re to the circle of tape. The fluorescent response from such a covered adhesive tape, if the surface was ful1y coated with glass, was found to be reproducible within a few percent. The choice of adhesive film for this purpose was important because we were interested in determining manganese and this element was found to be present in many of the commercial tapes that were tested. The tape cited was relatively free of this component. Sample layers so prepared could be protected with a very thin covering layer of vyns film. Vyns films of less than ten micrograms persquare centimeter thickness were.tound to diminish the softest $\mathrm{X}$-rays measured, i.e., those from magnesium, by on $1 \mathrm{y}$ approximately two percent. The response of the Sacro Catino specimen prepared in this way was compared at the same time to the response of a number of similar specimens of previously analyzed ancient g1asses. A specimen prepared with pure silica was used as a subtraction blank.

The technical assistance of Mrs. Patricia wa1sh in running most of these analyses is grateful1y acknowledged: We are also indebted to Miss Elinor Norton for carrying out the colorimetric phosphorous determinations. Mr. Rutherford J. Gettens contributed extensive1y to the initial establishment of spectrographic analytical procedures for this study. 


\section{References}

1. E. V. Sayre and R. W. Smith, "Compositional Categories of Ancient Glass," Science 133,1824 (1961).

2. R. W. Smith, "Archaeological Evaluation of Analyses of Ancient Glass," p. 283 in Advances in Glass Technology, Part 2, F. R. Matson and G. E. Rindone, eds., P1enum Press, New York, 1963.

3. E. V. Sayre, "The Intentional Use of Antimony and Manganese in Ancient Glasses," p. 263 in Advances in Glass Technology, Part 2, F. R. Matson and G. E. Rindone, eds., Plenum Press, New York, 1963.

4. Sir Harry Garner, On Early piece of Glass from Eridu, Iraq, 18, Pt. 2, 147 (1956).

5. Sir Harry Garner, The Use of Imported and Native Cobalt in Chinese Blue and White, Orienta1 Art, Vol.II, No. 2, 8 (1956).

6. Y. P. Varshney, Glass in Ancient India, Glass Ind., Vo1. 31, 1950, pp. 632-634. See a1so E. R. Caley, Analyses of Ancient Glasses, 1790-1951, The Corning Museum of Glass, Corning, New York, 1962, pp. 50-51.

7. Appendix 2, p. 289 in Dupree, Shamshir Ghar:. Historic Cane Site in Kandahar Province, Afghanistan, Vo1. 46, part 2, Anthropologica1 Papers of the American Museum of Natural History, New York, 1.958.

8. A. A. Abdurazakov and M. A. Bezborodov, Chemical Investigations of Medieval Glasses from Central Asia, Uzbek Chemical Journal $\underline{3}$, 5-16 (1962).

9. R. W. Smith, private communication.

10. R. Ettinghausen, An Umaiyad Pound Weight, The Journal of the Wa1ters Art Galle ry 2, 73 (1939). 